\title{
Status Hukum Alih Fungsi Lahan Hak Guna Usaha (HGU) Perkebunan Menjadi Wilayah Pertambangan
}

\author{
Albert \\ Fakultas Hukum, Universitas PGRI Palangka Raya \\ dikirim: 23 Desember 2021 direvisi:27 Desember 2021 diterima: 29 Desember 2021
}

\begin{abstract}
Abstrak:
Penelitian ini adalah tentang status lahan hak guna usaha untuk perkebunan yang beralih fungsi menjadi wilayah pertambangan. Metode penelitiannya adalah metode penelitian normatif, dengan elaborasi permasalahan tentang status hukum terhadap lahan HGU untuk perkebunan sawit dan karet yang beralih fungsi menjadi wilayah pertambangan. Dari penelitian tersebut, menunjukkan bahwa ternyata telah terjadi pengaplingan-pengaplingan wilayah tanah Indonesia dengan kuasa pertambangan atau Ijin Usaha Pertambangan telah terjadi dimana-mana, penerbitan Kuasa-kuasa penambangan tanpa memperhatikan kebijakan-kebijakan yang telah dibuat sektor-sektor lain sehingga menyebabkan disikronisasi kebijakan yang bersifat vertikal maupun horizontal. Pemegang kuasa pertambangan telah memberikan iuran kepada negara atas kesempatan menambang sesuai dengan ketentuan yang berlaku, pembayaran semacam iuran lain kepada Negara, karena pemakaian tanah permukaan bumi tetap diadakan, karena sifatnya berlainan dari iuran dalam bidang pertambangan.Tetapi kepada yang bersangkutan dapat diberikan, akan ditetapkan lebih lanjut oleh Menteri yang bersangkutan. Di dalam dalam usaha perolehan hak atas tanah untuk kepentingan umum pemegang hak atas tanah akan dihantui suatu perasaan bahwa nantinya apabila tidak tercapai kesepakatan hak atas tanahnya akan dicabut. Sedangkan dalam perolehan hak tanah selain kepentingan umum, pemegang hak atas tanah tidak ada rasa ketakutan bahwa hak atas tanahnya akan dicabut.
\end{abstract}

Kata Kunci : Status Lahan Hak Guna Usaha, Sektor Perkebunan dan Kehutanan, Alih Fungsi.

\begin{abstract}
:
This study is about the status of land use rights for plantations that have been converted into mining areas. The research method is a normative research method, with the elaboration of issues regarding the legal status of $\mathrm{HGU}$ land for oil palm and rubber plantations that have been converted into mining areas. From this research, it shows that turns out that there have been divisions of Indonesian land areas with mining authorizations or mining business permits that have occurred everywhere, the issuance of mining authorizations without paying attention to the policies that have been made by other sectors, causing a synchronization of procedures that is either vertical or horizontal. The mining authorization holder has made contributions to the state for mining opportunities following applicable regulations, payments such as other contributions to the state because the use of the earth's surface is still held. After all, its nature is different from assistance in the mining sector further by the Minister concerned. In the effort to acquire land rights for the public interest, the holder of land rights will be haunted by a feeling that later if no agreement is reached, the land rights will be revoked. Meanwhile, in acquiring land rights other than in the public interest, the holder has no fear that their land rights will be canceled..
\end{abstract}

Keywords : Land Use Rights Status, Plantation and Forestry Sector, Functional shift. 
Morality: Jurnal Ilmu Hulkum

\section{PENDAHULUAN}

Kegiatan pertambangan sudah lama dikenal oleh masyarakat Indonesia, hal ini dapat dilihat dari fakta sejarah yang membuktikan bahwa masyarakat dipulau Sumatra, Jawa dan Kalimantan telah melakukan kegiatan pertambangan sejak ribuan tahun yang lalu.Namun pada masa pemerintahan Hindia-Belanda berkuasa di Indonesia sektor pertambangan baru dikembangkan pada akhir abad 19 (Badaruddin, 2018), sedangkan pada masa pendudukan Jepang sektor pertambangan tidak berkembang karena orientasinya untuk memenuhi kebutuhan perang saja (Hayati, 2015).

Pada masa pemerintahan pasca kemerdekaan dan orde lama perkembangan sektor pertambangan mengalami pasang-surut sesuai dengan kondisi sosial politik yang terjadi.Pada masa orde baru ditandai dengan perubahan besar dalam tatanan kehidupan masyarakat yakni paradigma pembangunan yang menitikberatkan pertumbuhan ekonomi yang didukung dengan stabilitas nasional.Sejalan dengan paradigma pembangunan tersebut maka kebijakan sektor pertambangan yang diterapkan berorientasi pada pengembangan sektor industri sebagai pendukung utama pembangunan,hal ini terlihat dari parameter yang digunakan sebagai tolak
Desember 2021, Volume 7 Nomor 2

ukurnya yaitu besaran-besaran investasi, penerimaan negara, volume dan nilai ekspor yang dihasilkan dan sumbangan sector pertambangan terhadap pendapatan domestik bruto (PDB) nasional (Huraerah, 2008).

Untuk mendukung paradigma sektor pertambangan tersebut pemerintah mengeluarkan regulasi peraturan yakni Undang-undang Nomor 1 Tahun 1967 tentang Penanaman Modal (UUPM) jo. Undang-undang Nomor 6 Tahun 1968 tentang Penanaman Modal Dalam Negeri (UUPMDN), kemudian dikeluarkan Undang-undang Nomor 11 Tahun 1967 tentang Ketentuan-ketentuan Pokok Pertambangan (Azhari \& Salim, 2010).

Pada masa reformasi sektor pertambangan mendapatkan angin segar ditengah proses arus perdagangan bebas yang mengakibatkan industri pertambangan khususnya Batubara menjadi primadona untuk menambah devisa negara, dan untuk mendukung proses kebangkitan tersebut pada Desember 2008 pemerintah melakukan revisi Undang-undang Nomor 11 Tahun 1967 tentang Ketentuan-ketentuan Pokok Pertambangan dengan mengeluarkan Undang-Undang Nomor 4 Tahun 2009 tentang Pertambangan Mineral dan Batubara yang mana perubahan mendasar adalah berubahnya bentuk pengelolaan 
Morality: Jurnal Ilmu Hukum

sumber daya mineral dan pertambangan dari rezim kontrak menjadi rezim perizinan serta pengakuan adanya kegiatan pertambangan rakyat dalam suatu wilayah pertambangan.

Bukti semakin pentingnya industri pertambangan Batubara dalam Peraturan Presiden Nomor 5 Tahun 2010 tentang Rencana Pembangunan Jangka Menengah Nasional (RPJMN) Tahun 2010-2014 ditegaskan bahwa sampai saat ini telah dicapai berbagai hasil dan kemajuan disektor pertambangan mineral dan Batubara. Hasil ini merupakan tumpuan yang kuat memasuki pembangunan jangka menengah mendatang.

Penambangan di Indonesia terutama sekali penambangan batubara sebagian besar dilakukan dengan menggunakan penambangan sistem terbuka (Manik, 2013). Penggunaan metode penambangan sistem terbuka banyak digunakan karena tidak memerlukan teknologi yang rumit dan biaya investasi lebih rendah dibandingkan dengan pertambangan bawah tanah (under ground), hal ini dimungkinkan karena umumnya keberadaan batubara berada pada lapisan tanah permukaan. Sistem penambangan terbuka tersebut, maka tidak dapat dihindari memunculkan konflik dengan hak-hak kepemilikan atas tanah yang termasuk dalam areal ijin usaha
Desember 2021, Volume 7 Nomor 2

pertambangan. Abrar Saleng menyatakan bahwa permasalahan dalam kegiatan pengusahaan pertambangan adalah tumpang tindih hak atas wilayah operasi kontrak karya,kontrak production sharing, perjanjian karya pengusahaan pertambangan batubara dan kuasa pertambangan disatu pihak dengan hakhak seperti hak-hak yang terdapat dibidang kehutanan, perkebunan,ulayat masyarakat adat,transmigrasi dan tanah penduduk setempat dipihak lain (Saleng, 2004).

Dalam TAP MPR No.IX/MPR/2001 tentang Pembaharuan Agraria dan Pengelolaan Sumber Daya alam, menyatakan bahwa terdapat dampak negatif dari pengelolaan sumber daya alam dewasa ini seperti terjadinya penurunan kualitas lingkungan, terjadinya ketimpangan struktur penguasaan, pemilikan, penggunaan dan pemanfaatannya serta menimbulkan berbagai konflik, bahkan peraturan perundang-undangan yang berkaitan dengan pengelolaan sumber daya agraria atau sumber daya alam saling tumpang tindih. Pernyataan TAP MPR No.IX/MPR/2001 harus mendapatkan perhatian serius dari berbagai pihak yang menjadikan kebijakan lintas sektoral yang "saling tumpang tindih" baik dari segi kewenangan pengelolaan, kewenangan penguasaan maupun aspek regulasinya. 
Morality: Jurnal Ilmu Hukum

Fakta yang tak dapat dipungkiri adalah terjadinya "pengaplinganpengaplingan" wilayah tanah Indonesia dengan kuasa pertambangan atau Ijin Usaha Pertambangan telah terjadi dimanamana, penerbitan Kuasa-kuasa penambangan tanpa memperhatikan kebijakan-kebijakan yang telah dibuat sektor-sektor lain seperti Badan Pertanahan Nasional, Departemen Pertanian dan Perkebunan,Departemen Kehutanan sehingga menyebabkan disikronisasi kebijakan yang bersifat vertikal maupun horizontal sebagaimana diakui TAP MPR.No.IX Tahun 2001 tersebut diatas.

Salah satu fakta untuk "memotret" permasalahan tersebut di Kalimantan Selatan yaitu terjadinya konflik dan tumpang tindih antara kegiatan lahan untuk pemanfaatan Sumber Daya Alam (SDA) dengan kegiatan pertambangan antara PT. Adaro Indonesia sebagai pemegang Kuasa Pertambangan/Ijin Usaha Pertambangan dengan perusahaan perkebunan PT.Astra Agro Lestari, dimana sejak tahun 1991 terjadi tumpang tindih wilayah kerja kuasa pertambangan PT. Adaro Indonesia dengan lahan perkebunan hak guna usaha seluas 7.163 hektar di kecamatan Murung Pudak kabupaten Tabalong dan Juai/Halong kabupaten Balangan dari anak perusahaan
Desember 2021, Volume 7 Nomor 2

Astra Agro sehingga setelah 12 tahun masalah tumpang tindih ini maka pada tanggal 29 Pebruari 2008 PT.Astra Agro Lestari, PT.Cakradenta Agung Pertiwi, PT.Cakung Permata Nusa dan PT.Adaro Indonesia menandatangani “ Perjanjian Penyelesaian Bersyarat Mengenai Areal Tumpang-Tindih Kebun dan Tambang "(Conditional Settlement Agreement for Mining-Plantation Overlapping Areas).

Secara substansial kasus tersebut pada intinya adalah konflik kewenangan dan kepemilikan atas suatu wilayah pertambangan yang diatasnya tanah yang diberikan Kuasa Pertambangan/Ijin Usaha Pertambangan telah ada sesuatu hak atas tanah yang dalam hal ini adalah Hak Guna Usaha (HGU) dimana lahan Hak Guna Usaha beralih fungsi menjadi Wilayah Kuasa Pertambangan , yang mana keduanya sama-sama mendapatkan penetapan dari Pemerintah sehingga sudah semestinya sama-sama juga mendapatkan perlindungan hukum dari Negara/Pemerintah.

Tujuan penelitian ini adalah untuk mengetahui status hukum terhadap lahan HGU untuk perkebunan beralih fungsi menjadi wilayah pertambangan.

Metode yang digunakan adalah penelitian yuridis normatif, yakni penelitian yang difokuskan untuk mengkaji penerapan aturan maupun 
Morality: Jurnal Ilmu Hukum

kaidah-kaidah/norma-norma dalam hukum positif (Diantha \& SH, 2016), yakni berupa penelitian kepustakaan bersumberkan bahan-bahan hukum berupa bahan hukum primer,bahan hukum sekunder dan bahan hukum tersier, Penelitian ini dikaji dengan menggunakan peraturan hukum dan kasus-kasus hukum berkenaan dengan status lahan perkebunan menjadi lahan pertambangan.

\section{PEMBAHASAN}

Undang-Undang Nomor 4 Tahun 2009 adalah dasar yang mengatur tentang kegiatan pertambangan di Indonesia, sebagaimana pengganti Undang-Undang Nomor 11 Tahun 1967 tentang KetentuanKetentuan Pokok Pertambangan, meskipun demikian sebagaimana disebutkan pada BAB XXVI Ketentuan Penutup Pasal 173 Undang-Undang Nomor 4Tahun2009, bahwa:

(1) Pada saat Undang-Undang ini mulai berlaku, Undang- Undang Nomor 11 Tahun 1967 tentang KetentuanKetentuan Pokok Pertambangan (Lembaran Negara Republik Indonesia Tahun 1967 Nomor 22, Tambahan Lembaran Negara Republik Indonesia Nomor 283 1) dicabut dan dinyatakan tidak berlaku.

(2) Pada saat Undang-Undang ini mulai berlaku, semua Peraturan Perundangundangan yang merupakan peraturan
Desember 2021, Volume 7 Nomor 2

pelaksanaan dari Undang-Undang No 11 Tahun 1967 tentang KetentuanKetentuan Pokok Pertambangan (Lembaran Negara Republik Indonesia Tahun 1967 Nomor 22, Tarnbahan Lembaran Negara Republik Indonesia Nomor 283 1) dinyatakan masih tetap berlaku sepanjang tidak bertentangan dengan ketentuan dalam UndangUndang ini.

Pasal 51 Peraturan Pemerintah Republik Indonesia Nomor 32 Tahun 1969:

(1) Apabila telah diberikan Kuasa Pertambangan pada sebidang tanah yang diatasnya tidak terdapat hak tanah, dan Pemegang Kuasa Pertambangan yang bersangkutan telah membayar Iuran Tetap termaksud dalam pasal-pasal 53, 54 dan 55 Peraturan Pemerintah ini, maka kepadanya diberikan keringanan pembayaran beban-beban dan biayabiaya untuk pemakaian bumi permukaan tanah. Penjelasan dari pasal 51 : Ketentuan dalam pasal ini dapat pula diartikan suatu prioritas bagi pemegang kuasa pertambangan pada sebidang tanah diatas tidak terdapat hak tanah untuk mendapatkan hak pakai atas tanah tersebut.

(2) Keringanan pembayaran termaksud pada ayat (1) pasal ini ditentukan 
Morality: Jurnal Ilmu Hukum

bersamaoleh Menteri dan Menteri yang bertugas meliputi bidang agraria atau dengan Menteri lain yang bersangkutan.

Dalam Angka 5 Penjelasan Peraturan Pemerintah Republik Indonesia Nomor 32 Tahun 1969 yang berhubungan dengan Hubungan antara Kuasa Pertambangan dengan Hak-hak atas tanah: Mengenai hal ini telah diatur dengan teliti dalam Undang-Undang Pokok Pertambangan itu sendiri, sehingga dengan demikian hal tersebut tidak perlu diulang-ulangi lagi dalam Peraturan Pemerintah ini.

Begitupun ketentuan tentang pemakaian dan penggunaan atas tanah permukaan bumi telah pula diatur oleh Undang-Undang Pokok Agraria.Sebagai pendekatan untuk kesatuan tindakan pemerintah terhadap usaha yang menggunakan kesempatan melakukan usaha pertambangan yang dalam pelaksanaannya berhubungan pula dengan tanah permukaan bumi, maka diadakan keringanan.

Sungguhpun pemegang kuasa pertambangan telah memberikan iurannya kepada negara atas kesempatan menambang sesuai dengan ketentuan Peraturan Perundang-undangan yang berlaku, pembayaran semacam iuran lain kepada Negara, karena pemakaian tanah permukaan bumi tetap diadakan, karena
Desember 2021, Volume 7 Nomor 2

sifatnya berlainan dari iuran dalam bidang pertambangan.Tetapi kepada yang bersangkutan dapat diberikan, akan ditetapkan lebih lanjut oleh Menteri yang bersangkutan.

Jika diperhatikan ketentuanketentuan tersebut secara berdiri sendiri tanpa memperhatikan peraturan perundang-undangan lainnya, maka tidak ada celah hukum satupun atau peluang bagi usaha pertambangan untuk memanfaatkan tanah Hak Guna Usaha, tetapi jika dihadapkan dengan ketentuan perundang-undangan mengenai Pertambangan, maka dimungkinkan adanya celah bagi usaha pertambangan untuk pemanfaatan galian batubara diatas tanah Hak Guna Usaha yakni melalui mekanisme kesepakatan dengan Pemegang Hak Guna Usaha.

Dalam peraturan perundangundangan di Indonesia dapat dijumpai berbagai peristilahan/konsep mengenai ganti rugi. Dalam UUPA, Undang-Undang Nomor 20 Tahun 1961, Peraturan Pemerintah Nomor 39 Tahun 1973, dalam Keppres Nomor 55 Tahun 1993, Keputusan Menteri Negara Agraria/Kepala BPN Nomor 21 Tahun 1994 menggunakan istilah/konsep ganti kerugian.

Sedangkan dalam Permendagri Nomor 15 Tahun 1975 dan Perpres Nomor 36 Tahun 2005 sebagaimana telah diubah 
Morality: Jurnal Ilmu Hukum

dengan Perpres 65 Tahun 2006 menggunakan istilah ganti rugi. Dalam peraturan tersebut yang dimaksud dengan ganti kerugian adalah penggantian atas nilai tanah berikut bangunan, tanaman dan atau benda-benda lain yang terkait dengan tanah sebagai akibat pelepasan atau penyerahan hak atas tanah.

Sedangkan ganti rugi adalah penggantian terhadap kerugian baik bersifat fisik dan/atau non fisik sebagai akibat pengadaan tanah kepada yang mempunyai tanah, bangunan, tanaman, dan/atau benda-benda lain yang berkaitan dengan tanah yang dapat memberikan kelangsungan hidup yang lebih baik dari tingkat kehidupan sosial ekonomi sebelum terkena pengadaan tanah.

Dari kedua konsep tersebut menunjukkan adanya kesamaan yakni merupakan penggantian terhadap tanah, bangunan, tanaman, dan/atau benda-benda lain yang terkait dengan tanah sebagai akibat adanya pengadaan tanah (yang dilakukan dengan cara pelepasan/penyerahan). Perbedaannya dalam konsep ganti rugi memberikan kewajiban kepada pihak yang memerlukan tanah bahwa penggantian tersebut dapat memberikan kelangsungan hidup yang lebih baik dari tingkat kehidupan sosial ekonomi sebelum terkena pengadaan tanah.
Desember 2021, Volume 7 Nomor 2

Sebagaimana diuraikan diatas bahwa konsep perolehan hak atas tanah dibedakan untuk kepentingan umum maupun selain kepentingan umum. Dalam usaha perolehan hak atas tanah untuk kepentingan umum maka hanya dapat dilakukan dengan cara pelepasan atau penyerahan hak atas tanah yang sebelumnya didahului oleh adanya musyawarah untuk menentukan bentuk dan besarnya ganti kerugian.

Pelepasan hak milik atas tanah dapat dilakukan dengan akta yang menyatakan bahwa hak yang bersangkutan telah dilepaskan oleh pemegang haknya, secara notariil atau bawah tangan, yaitu dengan:

1. Akta notaris yang menyatakan bahwa pemegang yang bersangkutan melepaskan hak atas tanah, atau

2. Surat keterangan dari pemegang hak bahwa pemegang hak yang bersangkutan melepaskan hak atas tanah yang dibuat di depan dan disaksikan oleh Camat letak tanah yang bersangkutan, atau

3. Surat keterangan dari pemegang hak bahwa pemegang hak yang bersangkutan melepaskan hak atas tanah yang dibuat di depan dan disaksikan oleh Kepala Kantor Pertanahan setempat.

Dasar hukumnya bisa dilihat dalam Pasal 131 ayat 3 PMNA/Ka BPN No. 3 
Morality: Jurnal Ilmu Hukum

tahun 1997, dimana disebutkan bahwa Pelepasan Hak atas tanah dilakukan dengan:

1. Dengan Akta Notaris ;

2. Dibuat dihadapan Camat dimana tanah tersebut berada ;

3. Didepan Kepala Kantor Pertanahan setempat.

Ada beberapa syarat pelepasan hak atas tahan menurut para ahli hukum yaitu:

1. Menurut Andi S. Hutagalaung, pelaksanaan pelepasan hak ats tanah dilaksanakan apabila subjek yang memerlukan tanah tidak memenuhi syarat untuk menjadi pemegang hak atas tanah yang diperlukan sehingga tidak dapat diperoleh dengan jual beli dan pemegang hak atas tanah bersedia untuk melepaskan hak atas tanahnya. Acara pelepasan hak wajib dilakukan dengan surat pernyataan pelepasan hak tersebut dilakukan oleh pemegang hak atas tanah dengan suka rela.

2. Menurut notaris Irma Devita Purnamasari, pelaksanaan pelepasan hak atas tanah dilakukan diatas surat atau akta yang dibuat dihadapan notaris yang menyatakan bahwa pemegang hak yang bersangkutan telah melepaskan hak atas tanahnya.

Ada beberapa jenis pelepasan hak atas tanah, yakni:
Desember 2021, Volume 7 Nomor 2

1. Penghibaan, adalah pemberian seseorang kepada orang lain dengan tidak ada penggantian apa pun dan dilakukan secara suka rela tanpa ada kontraprestasi dari penerima pemberian, dan pemberian itu dilangsungkan pada saat si pemberi masih hidup.

2. Jual beli, menurut hukum adat jual beli adalah Suatu perbuatan pemindahan hak atas tanah yang bersifat terang dan tunai.

3. Perwakafan, menurut Moh. Anwar, sebagaimana dikutip Adrian Sutedi, menegaskan bahwa: menahan suatu barang dari dijualbelikan atau diberikan atau dipinjamkan oleh pemilik, guna dijadikan manfaat untuk kepentingan tertentu yang diperbolehkan oleh syara' serta tetap bentuknya, dan boleh dipergunakan, diambil manfaatnya oleh orang yang ditentukan (yang menerima wakaf), atau umum.

4. Pewarisan adalah perolehan hak milik yang diberikan oleh pewaris (orang yang punya hak untuk melepaskan hak yang dimilikinya kepada ahli warisnya) sehingga menjadi kepunyaan si yang menerima warisan.

5. Kepentingan adalah suatu kepentingan yang lebih memperioritaskan 
Morality: Jurnal Ilmu Hukum

kepentingan orang banyak, dapat melalui sebuah musyawarah.

Dalam hal musyawarah tidak tercapai kesepakatan maka panitia pengadaan tanah menetapkan besarnya ganti rugi dan menitipkan ganti rugi ke Pengadilan Negeri yang wilayah hukumnya meliputi lokasi tanah yang bersangkutan (Pasal 10 Perpres Nomor 36 Tahun 2005 sebagaimana telah diubah dengan Perpres Nomor 65 Tahun 2006). Berkaitan dengan penitipan ganti rugi ke pangadilan negeri (konsinyasi) sebelum adanya kesepakatan mengenai bentuk dan besarnya ganti rugi jelas tidak dapat dibenarkan, karena syarat adanya konsinyasi terlebih dahulu harus ada hubungan hukum.

Dengan belum tercapainya kesepakatan antara pemegang hak atas tanah dengan pihak yang memerlukan tanah maka berarti belum terjadi adanya hubungan hukum. Ketentuan mengenai konsinyasi diatur dalam Pasal 1404 BW yang menyebutkan:

"Jika si berpiutang menolak pembayaran, maka si berutang dapat melakukan penawaran pembayaran tunai apa yang diutangnya, dan jika si berpiutang menolaknya, menitipkan uang atau barangnya kepada pengadilan.Penawaran yang sedemikian, diikuti dengan penitipan, membebaskan si berutang, dan berlaku
Desember 2021, Volume 7 Nomor 2

baginya sebagai pembayaran, asal penawaran itu telah dilakukan dengan cara menurut undang-undang, sedangkan apa yang dititipkan secara itu tetap atas tanggungan si berpiutang."

Dari ketentuan Pasal 1404 BW tersebut maka antara pihak debitor dan kreditor harus ada hubungan hukum. Ketentuan yang terdapat dalam Pasal 10 Pepres tersebut jelas merupakan perampasan hak karena pihak pemegang hak atas tanah belum menyetujui bentuk dan besarnya ganti rugi. Senada dengan uraian tersebut di atas Sri Hajati mengemukakan bahwa:

"Ketentuan Pasal 10 ayat (2) Perpres Nomor 36 Tahun 36 tahun 2005 merupakan bentuk tidak adanya penghormatan terhadap hak atas tanah oleh Panitia Pengadaan Tanah padahal ini menjadi prinsip dalam Perpres 36 Tahun 2005. Upaya menitipkan ganti rugi ke Pengadilan Negeri merupakan bentuk kesewenang-wenangan Panitia Pengadaan Tanah terhadap pemegang hak atas tanah (Hajati, 2019).”

Di dalam Perpres tersebut nampak adanya inkonsistensi dalam perolehan hak atas tanah yakni selain diatur mengenai konsinyasi diatur pula pemberian kesempatan kepada pemegang hak atas tanah yang tidak menerima keputusan Panitia Pengadaan Tanah dapat 
Morality: Jurnal Ilmu Hukum

mengajukan keberatan kepada

Bupati/Walikota atau Gubernur atau

Menteri Dalam Negeri sesuai dengan kewenangannya disertai dengan penjelasan mengenai sebab-sebab dan alasan keberatan tersebut. Jadi disisi lain memaksa pemegang hak atas tanah dengan cara menitipkan ganti rugi tapi disisi lain masih memberi kesempatan kepada pemegang hak atas tanah untuk mengajukan keberatan.

Setelah mendengar dan mempelajari pendapat dan keinginan dari pemegang hak atas tanah serta pertimbangan Panitia Pengadaan Tanah, Bupati/Walikota, atau Gubernur, atau Menteri Dalam Negeri sesuai kewenangannya mengeluarkan keputusan yang dapat mengukuhkan atau mengubah keputusan Panitia Pengadaan Tanah mengenai bentuk dan besarnya ganti rugi yang akan diberikan.

Apabila upaya penyelesaian yang ditempuh oleh Bupati/Walikota atau Gubernur atau Menteri Dalam Negeri tetap tidak diterima oleh pemegang hak atas tanah dan lokasi pembangunan yang bersangkutan tidak dapat dipindahkan, maka Bupati/Walikota atau Gubernur atau Menteri Dalam Negeri sesuai kewenangan mengajukan usul penyelesaian dengan cara pencabutan hak atas tanah berdasarkan Undang-Undang Nomor 20 Tahun 1961 tentang Pencabutan Hak-Hak Atas Tanah
Desember 2021, Volume 7 Nomor 2

Dan Benda-Benda Yang Ada Di Atasnya.Sedangkan untuk perolehan hak atas tanah selain kepentingan umum, apabila musyawarah tidak tercapai kesepakatan maka tidak dapat dilakukan pencabutah hak atas tanah berdasarkan Undang-Undang nomor 20 Tahun 1961.

Dari uraian di atas jelaslah bahwa dalam usaha perolehan hak atas tanah untuk kepentingan umum pemegang hak atas tanah akan dihantui suatu perasaan bahwa nantinya apabila tidak tercapai kesepakatan hak atas tanahnya akan dicabut. Sedangkan dalam perolehan hak tanah selain kepentingan umum, pemegang hak atas tanah tidak ada rasa ketakutan bahwa hak atas tanahnya akan dicabut. Jadi dalam perolehan hak atas tanah selain kepentingan umum benar-benar di dasarkan pada kesepakatan, dalam arti bahwa para pihak saling menyatakan kehendak masing-masing, dan pernyataan pihak yang satu cocok dengan pernyataan yang lain (Nieuwenhuis, 1985).

Jadi tidak ada tekanan sama sekali. Oleh karena itu tidak ada pula pihak yang merasa dirugikan. Berbeda dengan perolehan hak atas tanah untuk kepentingan umum, dimana instansi yang memerlukan punya kekuatan untuk menekan atau memaksa pemegang hak atas tanah untuk menyerahkan/melepaskan hak atas tanahnya. 
Morality: Jurnal Ilmu Hukum

Dengan demikian tidak tepat menggunakan istilah/konsep ganti rugi ataupun ganti kerugian dalam perolehan hak atas tanah selain untuk kepentingan umum. Di dalam tulisan ini saya menawarkan adanya suatu konsep kompensasi untuk perolehan hak atas tanah selain kepentingan umum, sedangkan untuk perolehan hak atas tanah untuk kepentingan umum dapat digunakan konsep ganti rugi/ganti kerugian.

Landasan hukum penetapan ganti kerugian menurut Peraturan Menteri Dalam Negeri (PMDN) Nomor 15 Tahun 1975 tentang Ketentuan-Ketentuan Mengenai Tata Cara Pembebasan Tanah, Keputusan Presiden (Kepres) Nomor 55 Tahun 1993tentangPengadaan Tanah Bagi Pelaksanaan

Pembangunan

UntukKepentingan Umum dan Peraturan Presiden (Perpres) Nomor 36 Tahun 2005 tentang Pengadaan Tanah Bagi Pelaksanaan Pembangunan Untuk Kepentingan Umum yaitu sama-sama atas dasar musyawarah. Adapun pengertian ganti rugi menurut Pasal 1 ayat (11) Peraturan Presiden (Perpres) Nomor 36 Tahun 2005 tentang Pengadaan Tanah Bagi Pelaksanaan Pembangunan Untuk Kepentingan Umum yaitu ganti kerugian ialah penggantian terhadap kerugian baik bersifat fisik dan/atau nonfisik sebagai akibat pengadaan tanah kepada yang
Desember 2021, Volume 7 Nomor 2

mempunyai tanah, bangunan, tanaman, dan/atau benda-benda lain yang berkaitan dengan tanah, yang dapat memberikan kalangsungan hidup yang lebih baik dari tingkat kehidupan sosial ekonomi sebelum terkena pengadaan tanah.

Kompensasi sebenarnya berasal dari bahasa Inggris compensation yang diterjemahkan dalam bahasa Indonesia adalah ganti rugi, akan tetapi konsep kompensasi ini saya tawarkan untuk membedakan bahwa dalam kompensasi ini digunakan dalam perolehan hak atas tanah selain kepentingan umum dan benar-benar didasarkan pada kesepakatan yang lahir tanpa adanya tekanan dan kekawatiran bagi pemegang hak atas tanah bahwa kalau tidak sepakat tanahnya akan dicabut.

Di dalam BW juga dikenal adanya konsep ganti kerugian, akan tetapi pengaturan mengenai ganti kerugian yang ada dalam BW adalah lebih luas, yakni ganti kerugian sebagai akibat adanya perbuatan melanggar hukum dan wanprestasi maupun ganti kerugian tanpa adanya pelanggaran hukum dan tanpa adanya wanprestasi.

Misalnya ganti kerugian oleh perusahaan asuransi. J.H. Neuwenhuis mengemukakan pengertian kerugian adalah berkurangnya harta kekayaan pihak yang satu, yang disebabkan oleh perbuatan (melakukan atau membiarkan) yang 
Morality: Jurnal Ilmu Hukum

melanggar norma oleh pihak lain. Dengan demikian ganti rugi adalah penggantian oleh pihak lain atas berkurangnya harta kekayaan pihak yang satu, yang disebabkan oleh perbuatan (melakukan atau membiarkan) yang melanggar norma oleh pihak lain tersebut.

Ganti rugi lazimnya dalam bentuk sejumlah uang, tetapi dapat pula berbentuk lain. Sedangkan ganti rugi maupun kompensasi yang ada dalam perolehan hak atas tanah tanpa didahului adanya perbuatan melanggar hukum ataupun wanprestasi.

Untuk berbagai kasus tuntutan masyarakat terhadap PT.CPN, PT,ATA dan PT.Adaro Indonesia terlihat bahwa pihak perusahaan kesulitan untuk memahami bagaimana memenuhi tuntutan masyarakat terhadap pelepasan hak atas tanah dari masyarakat, untuk itu ada baiknya dikemukakan beberapa alternatif penyelesaian sengketa tanah PT.CPN, PT.ATA dan PT.Adaro Indonesia dengan masyarakat yang menuntut ganti rugi dengan cara-cara sebagai berikut:

a. Jual Beli Hak Atas Tanah

Sebagaimana disebutkan dalam Pasal 5

UUPA bahwa hukum agraria yang berlaku atas bumi, air dan ruang angkasa ialah hukum adat. Hukum tanah yang merupakan hukum agraria dalam arti sempit tentu juga di
Desember 2021, Volume 7 Nomor 2

dasarkan pada hukum adat. Syarat untuk sahnya jual beli tanah menurut hukum adat adalah terpenuhinya tiga unsur, yakni tunai, riil dan terang.

Yang dimaksud dengan tunai adalah bahwa penyerahan hak oleh penjual dilakukan bersamaan dengan pembayaran oleh pembeli dan seketika itu juga hak sudah beralih. Harga yang dibayarkan itu tidak harus lunas, selisih harga dianggap sebagai utang pembeli kepada penjual yang termasuk dalam lingkup hukum utang piutang. Sifat riil berarti bahwa kehendak yang diucapkan harus diikuti dengan perbuatan nyata, misalnya dengan telah diterimanya uang oleh penjual dan dibuatnya perjanjian di hadapan kepala desa. Perbuatan hukum jual beli tanah tersebut disebut terang kalau dilakukan di hadapan kepala desa untuk memastikan bahwa perbuatan itu tidak melanggar ketentuan hukum yang berlaku.

Prinsip jual beli dalam hukum adat tersebut kemudian diangkat dalam hukum tanah nasional sebagaimana diatur dalam Pasal 37 ayat (1) Peraturan Pemerintah Nomor 24 Tahun 1997 yang menyatakan bahwa peralihan hak atas tanah dan hak milik atas satuan rumah susun melalui jual beli, tukar menukar, hibah, pemasukan 
dalam perusahaan dan perbuatan hukum pemindahan hak lainnya, kecuali pemindahan hak melalui lelang hanya dapat didaftarkan jika dibuktikan dengan akta yang dibuat oleh PPAT yang berwenang menurut ketentuan peraturan perundangundangan yang berlaku.

Boedi Harsono mengemukakan bahwa dalam memenuhi kebutuhan masyarakat modern yang terbuka lembaga jual beli tanah mengalami modernisasi dan penyesuaian, tanpa mengubah hakikatnya sebagai perbuatan hukum pemindahan hak atas tanah dengan pembayaran harganya secara tunai, serta sifat dan cirinya sebagai perbuatan riil dan terang.

Jual beli berdasarkan Pasal 37 diatas harus dibuktikan dengan akta PPAT. Hal tersebut merupakan suatu perubahan yang bertujuan untuk meningkatkan mutu alat bukti perbuatan hukum yang dilakukan, yang menurut hukum adatnya masyarakat yang terbatas lingkup personal dan teritorialnya, cukup dibuatkan aktanya oleh penjual sendiri dan diketahui oleh Kepala Desa/Adat. Perubahan tata cara ini bukan meniadakan ketentuan hukum adat yang mengatur segi materiil lembaga jual beli tanah.

b. Tukar Menukar Hak Atas Tanah
Dalam perolehan tanah dalam rangka lahan pertambangan maka dapat pula dimungkinkan adanya tukar menukar. Dalam pelaksanaan tukar menukar hak atas tanah pada prinsipnya sama dengan pelaksanaan jual beli yakni harus dibuat dengan akta PPAT. Namun perlu ditekankan bahwa pelaksanaan tukar menukar hak atas tanah itu harus tetap memperhatikan apakah para pihak yang melakukan tukar menukar tersebut dapat menjadi subyek hak atas tanah yang akan ditukarkan.

Hal di atas perlu mendapat perhatian karena tidak semua subyek hukum dapat menjadi subyek hak atas tanah tertentu. Misalnya subyek yang dapat menjadi subyek hak milik adalah warga negara Indonesia dan badan hukum tertentu yang diatur dalam Peraturan Pemerintah Nomor 38 Tahun 1963.

Ketentuan yang mengharuskan hanya warga negara Indonesia yang dapat menjadi subyek hak milik ini didasarkan pada prinsip nasionalitas yang terdapat dalam Pasal 1 ayat (1) UUPA yang menyebutkan bahwa seluruh wilayah Indonesia adalah kesatuan tanah air dari seluruh rakyat Indonesia, yang besatu sebagai bangsa Indonesia. 
Ketentuan Pasal 1 ayat 2 yang menyebutkan bahwa seluruh bumi, air dan ruang angkasa termasuk kekayaan alam yang terkandung didalamnya dalam wilayah Republik Indonesia sebagai karunia Tuhan Yang Maha Esa, adalah bumi, air dan ruang angkasa bangsa Indonesia dan merupakan kekayaan nasional. Sedangkan hubungan antara bangsa Indonesia dengan bumi, air dan ruang angkasa Indonesia adalah hubungan yang bersifat abadi. Ini berarti bahwa selama rakyat Indonesia bersatu sebagai bangsa Indonesia masih ada, demikian pula selama bumi, air dan ruang angkasa Indonesia masih ada pula, maka tida ada sesuatu kekuasaan apapun yang dapat memutuskan atau meniadakan hubungan tersebut (Nugraha, 2016).

Dengan demikian hanya warganegara Indonesia saja yang mempunyai hubungan yang sepenuhnya dengan bumi, air dan ruang angkasa, tanpa membedakan apakah itu laki-laki atau perempuan. Dengan demikian setiap warganegara baik laki-laki maupun perempuan mempunyai kesempatan yang sama untuk memperoleh sesuatu hak atas tanah serta untuk mendapatkan manfaat baik bagi diri sendiri maupun keluarganya. Untuk itulah maka hanya warganegara Indonesia saja yang dapat mempunyai hak milik atas tanah. Mengenai badan hukum sebenarnya tidak dapat mempunyai hak milik, tetapi mengingat akan keperluan masyarakat yang sangat erat hubungannya dengan masalah-masalah perekonomian maka diadakan escape-clause yang memungkinkan badan hukum dapat mempunyai hak milik atas tanah.

Dengan demikian badan-badan hukum yang ditunjuk oleh Pemerintah ini terbatas pada badan-badan hukum yang untuk penunaian tugas dan usahanya yang tertentu benar-benar memerlukan tanah dengan hak milik. Tetapi bagi badan-badan hukum yang memiliki tanah dengan hak milik itu tidaklah tidak terbatas, tetapi disertai pula syarat-syarat mengenai peruntukan dan luasnya.

Sedangkan untuk Hak Guna Usaha dan Hak Guna Bangunan subyeknya adalah Warga Negara Indonesia dan badan hukum Indonesia. Jadi jangan sampai terjadi tukar menukar antara badan hukum yang tidak ditunjuk oleh Peraturan Pemerintah Nomor 38 Tahun 1963, melakukan tukar menukar dengan warga negara Indonesia yang mempunyai hak milik atas tanah. 
Sebab hal ini apabila dilakukan akan berakibat batal demi hukum sebagaimana diatur dalam Pasal 26 ayat (2) UUPA. Selain itu perlu juga diperhatikan apakah sifat dari hak atas tanah itu juga dapat dipindahtangankan atau tidak.

c. Cara Lain

Perolehan tanah selain dengan cara jual beli, tukar menukar juga dapat dilakukan dengan cara lain. Cara lain yang dimaksud menurut Djuhaendah Hasan diantaranya adalah mengikutsertakan dalam pemilikan saham . Sedangkan dalam UndangUndang No. 21 Tahun 1997 Tentang Bea Perolehan Hak Atas Tanah Dan Bangunan sebagaimana telah diubah dengan Undang-Undang Nomor 20 Tahun 2000.

Demikian pula disebutkan dalam Peraturan Pemerintah Nomor 48 Tahun 1994 Tentang Pembayaran Pajak Penghasilan Atas Penghasilan Dari Pengalihan Hak Atas Tanah Dan/Atau Bangunan yang telah beberapa kali dilakukan perubahan yang terakhir dengan Peraturan Pemerintah Nomor 71 Tahun 2008, Permen Agraria/Kep. BPN Nomor 9 Tahun 1999, dan Keputusan Menteri Negara Agraria/Kepala BPN Nomor 21

Tahun 1994 perolehan hak dapat pula dilakukan dengan cara pelepasan hak atas tanah.

Berdasarkan Pasal 1 angka 3 Kepusan Menteri Negara Agraria/Kepala BPN Nomor 21 Tahun 1994 yang dimaksud pelepasan atau penyerahan hak atas tanah adalah kegiatan melepaskan hubungan hukum antara pemegang hak atas tanah dengan tanah yang dikuasainya dengan memberikan ganti kerugian atas dasar musyawarah.

Dari ketentuan tersebut nampak bahwa pelaksanaan pelepasan dilakukan apabila telah terjadi adanya kesepakatan mengenai bentuk dan besarnya ganti kerugian antara pemegang hak atas tanah dengan pihak yang memerlukan tanah. Dengan dilepaskannya hak atas tanah tersebut bukan berarti tanah tersebut langsung menjadi hak dari pihak yang memerlukan, akan tetapi status tanah tersebut menjadi tanah negara.

\section{KESIMPULAN}

Kegiatan pertambangan sudah lama dikenal oleh masyarakat Indonesia, hal ini dapat dilihat dari fakta sejarah yang membuktikan bahwa masyarakat dipulau Sumatra, Jawa dan Kalimantan telah melakukan kegiatan pertambangan sejak ribuan tahun yang lalu.Namun pada masa pemerintahan Hindia-Belanda berkuasa di Indonesia sektor pertambangan baru 
dikembangkan pada akhir abad 19. Dalam perkembangannya, telah terjadi pengaplingan-pengaplingan wilayah tanah Indonesia dengan kuasa pertambangan atau Ijin Usaha Pertambangan telah terjadi dimana-mana, penerbitan Kuasa-kuasa penambangan tanpa memperhatikan kebijakan-kebijakan yang telah dibuat sektor-sektor lain seperti Badan Pertanahan Nasional, Departemen Pertanian dan Perkebunan,Departemen Kehutanan sehingga menyebabkan disikronisasi kebijakan yang bersifat vertikal maupun horizontal.

\section{DAFTAR RUJUKAN}

Azhari, A. F., \& Salim, K. (2010). UUD 1945 SEBAGAI REVOLUTIEGRONDWET: Tafsir Poskolonial atas Gagasan-gagasan Revolusioner dalam Wacana Konstitusi Indonesia. LPPM UMS.

Badaruddin, M. (2018). Dynamics of the Oil and Gas and Mining Industry in Indonesia. In Jurnal Ilmu Politik (Hubungan Internasional) (Vol. 15).

Diantha, I. M. P., \& SH, M. S. (2016). Metodologi penelitian hukum normatif dalam justifikasi teori hukum. Prenada Media.

Hajati, S. (2019). Application of Agreement Principles in Land Procurement for Development Public Interest. Yuridika, 34(2), 365-386.

Hayati, T. (2015). Era Baru Hukum Pertambangan: Di Bawah Rezim UU No. 4 Tahun 2009. Yayasan Pustaka Obor Indonesia.
Huraerah, A. (2008). Pengorganisasian dan pengembangan masyarakat: model dan strategi pembangunan berbasis kerakyatan. Humaniora.

Kitab Undang-Undang Hukum Perdata

Manik, J. D. N. (2013). Pengelolaan Pertambangan Yang Berdampak Lingkungan Di Indonesia. PROMINE, 1(1).

Nieuwenhuis, J. H. (1985). Pokok-Pokok Hukum Perikatan, terjemahan Djasadin Saragih. Surabaya: Universitas Airlangga.

Nugraha, S. (2016). Peran Masyarakat Dalam Perlindungan Dan Pengelolaan Lingkungan Hidup Menurut UndangUndang Nomor 32 Tahun 2009 Tentang Perlindungan Dan Pengelolaan Lingkungan Hidup. Jendela Hukum, 3(1), 23-31. https://doi.org/10.24929/fh.v3i1.353

Peraturan Pemerintah Republik Indonesia Nomor 37 Tahun 1986 tentang Penyerahan sebagian urusan Pemerintahan di Bidang Pertambangan kepada Pemerintah Daerah Tingkat I

Peraturan Pemerintah Nomor 40 Tahun 1996 tentang Hak Guna Usaha,Hak Guna Bangunan dan Hak Pakai.

Peraturan Pemerintah Nomor 24 Tahun 1997 tentang Pendaftarann Tanah

Peraturan Pemerintah Nomor 75 Tahun 2001 tentang Perubahan Kedua atas Peraturan Pemerintah Nomor 32 Tahun 1969 tentang Peraturan Pelaksana Undang-Undang Nomor 11 Tahun 1967 tentang Pokok-pokok Pertambangan 
Saleng, A. (2004). Hukum pertambangan. UII press.

Undang-Undang Nomor 5 Tahun 1960 tentang Pokok-Pokok Agraria

Undang-Undang Nomor 3 Tahun 2020 Tentang Perubahan Atas UndangUndang Nomor 4 Tahun 2009 Tentang Pertambangan Mineral dan Batubara 